\title{
SYMBOLIC MEANING ANALYSIS OF KESANDINGAN RITUAL IN PROBOLINGGO
}

\author{
Nurhadi ${ }^{1}$, Faisol', and Faisal Mahmoud Adam Ibrahim ${ }^{2}$ \\ ${ }^{1}$ Universitas Islam Negeri Maulana Malik Ibrahim Malang, Indonesia \\ ${ }^{2}$ University of the Holy Quran and Islamic Sciences, Sudan \\ Email: nurhadi@pba.uin-malang.ac.id
}

Received: October 23, 2020

Accepted: May 19, 2021

\section{Abstract}

Kesandingan, one of the rituals in Probolinggo, East Java, is a cultural phenomenon that mingles with religious elements of society. It is something sacred and mystical that parents do when a toddler (an infant under three years old) experiences heat illness for days, tends to be fussy, cries a lot, and cannot sleep at night. This research aims to explain the process of symbolic communication of kesandingan ritual and to understand the symbolic meaning behind the ritual. It is a descriptive-qualitative study through observation, in-depth interviews, and documentation. The data analysis uses a qualitative-naturalistic technique. The result demonstrates that the symbolic communication process of kesandingan ritual in Mentor, Sumberasih, Probolinggo, comprises seven series: burning incense, wiping incense smoke on the child's face, giving the child holy water to drink, wiping the child with floral water, preparing food, making a wish on the child's bed, and distributing food. Meanwhile, the symbolic meaning of kesandingan ritual refers to divine, social and personal dimensions.

Ritual kesandingan merupakan salah satu ritual masyarakat Probolinggo Jawa Timur yang sudah menjadi fenomena budaya yang berbaur dengan unsur religi masyarakat. Ritual kesandingan merupakan sesuatu yang sakral dan mistis yang dilakukan orang tua saat anak batita (bawah tiga tahun) mengalami sakit 
panas berhari-hari, rewel, kerap menangis dan tidak bisa tidur terutama malam hari. Tujuan penelitian ini untuk menjelaskan proses komunikasi simbolik ritual kesandingan dan memahami makna simbolik dibalik ritual tersebuat. Penelitian ini merupakan penelitian deskriptif-kualitatif, pengumpulan datanya melalui observasi, wawancara mendalam, dan dokumentasi. Sedangkan analisis datanya menggunakan teknik analisa data kualitatif-naturalistik. Sebagai hasilnya, diketahui bahwa proses komunikasi simbolik ritual kesandingan di desa Mentor Kecamatan Sumberasih Kabupaten Probolinggo meliputi tujuh rangkaian yaitu: membakar kemenyan, mengusap asap kemenyan ke wajah anak, memberi minuman kepada anak dengan air doa, mengusap wajah anak dengan air bunga, menyiapkan makanan, memanjatkan doa ditempat tidur anak, dan membagikan makanan. Sedangkan makna simbolik ritual kesandingan mencakup tiga dimensi, yaitu: dimensi ketuhanan, sosial, dan personal.

Keywords: symbolic meaning; Kesandingan ritual

\section{Introduction}

Indonesian Islamic culture represents a distinctive identity with various rituals and practices, which combine traditional and Islamic teachings (Hilmi, 2020). Traditional healing is a socio-cultural phenomenon that thrives in remote communities where adequate health facilities are less accessible. Therefore, when people suffer from certain diseases, the main alternative is traditional healing through medicinal rituals believed to cure the disease.

Ritual is a series of ceremonials attached with magical elements carried out by certain groups of people. Ritual is a path for humans to safely and productively navigate the darkness and chaos when they are down (Watkins, 2019). The ritual elements include the place and time, the ritual process, the tools used, and the people who perform the ritual. Ritual is an important site of emotional exchange within survivor families (Sidorchuk, 2018) and that in adulthood, the children of survivors have engaged in ritual innovation to separate from their traumatized parents (Jacobs, 2011).

As a rich country in cultures, beliefs, and customs, various traditional healing rituals are easily found in almost all regions in Indonesia. One of them is the healing ritual of Turun Jin, which has been developed and passed down from the people of Rimba Melintang, Rokan Hilir Regency. The ritual of descending the genie is believed to be a ritual treatment for ailments, such as transmitted diseases, spirit disorders, fever, and serious illnesses (Kardila, 2016). 
Javanese syncretism lies in the belief in God, a supernatural power that synergizes with local culture. Javanese believe in the concept of a disease that commonly affects babies and children called sawan. Sawan is perceived to attack babies and children due to the act of invisible creatures.

Meanwhile, the term "kesandingan" is more familiar to the people in Probolinggo. Kesandingan is a ritual for the people of Probolinggo, East Java, to heal babies or children who experience disturbance by invisible creatures. It has become a cultural phenomenon that mingles with religious elements of society. The matching ritual is something sacred and mystical that parents do when a child experiences heat illness for days, tends to be fussy, cries a lot, and cannot sleep, especially at night. According to the indigenous people of Probolinggo, it occurs due to the act of the spirit (invisible creatures) of the ancestors, trying to communicate with the child. Javanese and partly Madurese are familiar with the term "ketempelan".

Probolinggo is a part of East Java, and Kraksaan is the center of the government. Probolinggo is also well known as the producer of shallots and mangoes. It has the dimensions of belief, tradition, customs, and other rituals. The society hold a strong Islamic nuance, so Islamic values and local culture is perfectly-acculturated. Islam in Probolinggo is unique in term of the practice and meaning.

The practice of traditional healing rituals among society in Probolinggo is also a unique cultural portrait. They still preserve it from generation to generation with beliefs from either a religious perspective or sociological features of the local community. When viewed from the study of cultural anthropology, it requires further exploration. The people around Mentor, Sumberasih Subdistrict, which comprises Darungan, Bendungan, and Kalicangkah hamlet consider the ritual of accompaniment as the main alternative to traditional healing when their toddlers have a fever, no appetite, and sleeping difficulty (Interview, 6 October 2018).

The ritual of "Kesandingan" is carried out as a tribute to the ancestral spirits and communication efforts that the subtle power does not disturb the toddlers, and they soon recover. This ritual is symbolic considering human is an animal symbolism. Many symbols have deep and specific meanings for ritual in pair. The meaning of symbols in the pair ritual is identifiable through symbolic interaction theory.

Helbert Blumer states that the urgency of meaning to one's actions includes one's attitude towards others based on meanings understood by them. 
Meaning is created as a result of human interactions modified through an interpretive process (Fisher, 1986). Humans do not only move because of the influence of stimuli both intrinsically and extrinsically, but they are creatures that are aware of themselves. Further, human relations in the community are influenced by socio-cultural processes and social structures manifested through social interaction. In addition, the meaning of symbols, which includes conditions and symbol, Blumer defines this level as non-symbolic and symbolic interaction (Fisher, 1986).

The Islamic rituals in Indonesia have been studied from several perspectives by many scholars (Manan, 2020; Munip, 2018; Ridwan \& Sulaeman, 2020; Sakai, 2017; Sari et al, 2020). The ritual observed in this study is related to communication actors that contain aspects of the soul. The use of meaningful symbols during the ritual has a special style that refers to certain point, and the symbolic meaning becomes the focus of this study.

\section{Method}

The current study is a field and qualitative descriptive research because the main data source is derived from the natural setting. The researcher is the key instrument. It explains the object descriptively focusing on the results rather than the process. In addition, the existing data are analyzed inductively and the meaning of each incident is the prioritized concern. This study uses a phenomenological study approach. Phenomenology is a study of something that appears or what appears or a phenomenon (Moleong, 2002).

The data collection techniques are observation, interview, and documentation. The participant observation covers a kinship approach to warm the atmosphere to understand each other's goals, so researchers are well accepted to get the intended information. This case includes adaptation by living with research subjects and participating in the activities within. The researchers also conduct sorting out social situations including places, actors, and activities. The focus of observations is the procession and the symbolic meaning of the kesandingan ritual. The documentation is done to explore primary and secondary data regarding the procession and symbolic meaning of kesandingan ritual in Probolinggo community.

The data analysis uses a qualitative-naturalistic analysis technique. Qualitative data analysis attempts to collect data, map data, classify them into manageable units, synthesize, search, critique, find patterns, find the focus 
of the study and what is learned, and decide which results have been found (Moleong, 2002).

In this case, the researchers use the Miles and Huberman's model. The first step is collecting data through observation, interviews and documentation. All data are descriptive according to what happens in the field. The next step is to reflect, interpret, and critically analyze them. Then, it proceeds with reducing data through classification, the subject of simplification, transformation of raw data from field subjects, classifying and eliminating unnecessary according to the focus of the problem. The next stage is presenting narratively from notes obtained in the field. The final step is drawing conclusion, it reviews the presentation of data and field notes through in-depth discussions with several competent informants (Sugiono, 2008).

\section{Symbolic Interaction Theory}

George Herber Mead was the initiator of the basic theory of symbolic interaction, but it was Helbert Blumer in 1937 who created and popularized it (Sobur, 2003). This theory explores human communication with the use of meaningful symbols. According to Blumer, man is the re-creator of his environment, the designer of his object world in the flow of his every action. Adherents to this theory argue that humans are moved to take action because of the meaning labeled with people, objects, and phenomena. This meaning is manifested through the language used to communicate with other people and himself or his thoughts.

The main points in this theory are: first, the urgency of meaning to one's actions includes one's attitude towards each other based on meanings that they understand. The meaning created by human interaction is modified through an interpretive process. Second, humans do not only move because the stimulus is good intrinsically or extrinsically, but they are beings who are aware of themselves. Third, human relations in the community are influenced by socio-cultural processes and social structures manifested through social interaction. Fourth, the meaning of symbols, including terms and symbols, Blumer defines this level as non-interaction and symbolic interactions (Fisher, 1986). Post-structural theory defines ritual action as the communication of meaning and the construction of reality, identity, and community (Sande, 2000).

Blumer's symbolic interactionism theory includes several basic ideas (Paloma, 2004). It covers; first, a collection of society contains humans who interact with each other. It occurs through collective action and forming social

el Harakah Jurnal Budaya Islam Vol. 23 No. 1 Tahun 2021 
structures. Second, the interaction between humans includes human activities with other humans. Non-symbolic interactions contain a response stimulus, so symbolic interactions contain interpretations of human action. Third, it is an intrinsically insignificant object. Meaning is the product of symbolic interaction. This object can be classified into three types: physical, social, and abstract object. Fourth, humans are unique creatures knowing external objects, but they also see themselves as objects. Fifth, all human actions are interpretive actions. Sixth, these actions are interrelated and in accordance with group members. It is a collective action which is continuous, stable, and can realize cultural values (Sobur, 2003).

Meanwhile, George Ritzer (in Mulyana, 2001) summarizes the theory into the principle that humans, unlike animals, are equipped with the ability to think. The ability to think is shaped by social interaction. During the social interaction, humans learn the meanings and symbols that enable them to use their special thinking abilities. Meanings and symbols allow humans to continue specific actions and interaction. They can change the meaning and symbols they use in actions and interactions based on their interpretation of situations. Humans can make modifications and change policies because of their ability to interact with themselves, which enables them to test a series of opportunities for action, assess their relative advantages and disadvantages, and select one of those courses of action. Interrelated patterns of action and interaction will form groups and communities.

\section{Symbolic and Ritual Communication}

Animal symbolic is the term for humans as creatures who use symbols, so there is a symbolic system that can distinguish between humans and other creatures. Humans are unique creatures with a lot of media used to communicate, such as speaking, using signs or symbols and words. In a cultural environment, people from generation to generation use special symbols believed to be a way to interact with their fellow communities.

According to Susanne K. Langer, basic human needs are symbolic such as eating, seeing, and moving. This is an important ongoing process of human logic. Therefore, human achievement depends on the symbols used (Sihabudin, 2011). In regard, ritual is a series of human activities packaged with customs or laws that the community believes, and it is related to various events that commonly occur among society (Koentjaraningrat, 1994).

el Harakah Jurnal Budaya Islam Vol. 23 No. 1 Tahun 2021 
According to Prawirorahardjono, human's ritual procedures are as follows: first, cleansing, such as washing the face, hands, feet, and other body parts just before starting the ritual. Second, clothing used in the ritual: clean, neat, and formal. They can also dress in white. Third, place of ritual: free, and it can be anywhere. Fourth, special ritual equipment: mats, lighting or candles. Fifth, preferred attitude: sitting continuously, closing eyes, hands can move freely and harmoniously, head/face is down and bowed. They can also be standing, sitting on a chair. Sixth, direction of concentration: can be free and harmonious. Seventh, a series of ritual prayer ceremonies: they can pray silently, say certain words in the hope of cleansing the spiritual and the mind and strengthening faith, and praying aloud while muttering quietly (Endaswara, 2002).

\section{Rituals or Rites and Ethnomedicine of Sawan and Kesandingan}

Ritual is a series of human activities to communicate with God, ancestral spirits, great gods or other invisible creatures. It is often conducted repeatedly in a certain moment, every month, every day or sometimes. It can be in the form of prayer, carrying offerings, eating together, preparing offerings, dancing or singing, shouting, posing, performing sacred dramas, fasting, and meditating (Koentjaningrat, 1985).

Meanwhile, ethnomedicine is the study of folk medicine, by classifying diseases, conducting therapy and traditional prevention. It is a belief and practice related to diseases originating from ancient cultural developments (Briggs \& Nichter, 2018) and not from the conceptual framework of modern medicine (Joyomartono, 2007). Sawanan is an event that is carried out because of violations of humans related to the norms of life that causes a baby or child disturbed by spirits (invisible creatures). Sanctions for violations can be in the form of certain symptoms or illnesses depending on the type of seizure that attacks them (Iskandar, 1981).

Sawan for most people sounds strange or illogical. However, they can easily deduce what happens based on the logic of thinking that is far from magic. Another thing in Java, which is thick with ancient culture and beliefs, sawan is considered a common disease in infants or children. There are even traditional shaman for babies and herbal medicine easily found in the community. Meanwhile, some people state that it is an epilepsy and seizure. However, some people think that epilepsy occurs because of the disturbance of invisible creatures, a curse and is sometimes associated with mental illness or

el Harakah Jurnal Budaya Islam Vol. 23 No. 1 Tahun 2021 
low intelligence. The term of sawan is also popular in Probolinggo, but there are striking differences in its definition and healing techniques. According to Suminah, one of the local people, Sawan is a seizure in a baby or small child, and there is no special ritual for healing. Usually, people immediately have their baby or child checked at the health center or hospital (Interview, 12 October, 2019).

Sawan is known as convulsions that happen to the child or baby, and there is no special ritual for healing because the people will bring the baby or child to public health center or hospital. The matching ritual is something sacred and mystical that parents do when toddlers experience hot pain for days, tend to be fussy, often cry, and can't sleep, especially at night. People in Probolinggo believe that it happens because the" invisible creatures" try to communicate with the child. Meanwhile, the term kesandingan for people in Probolingo is slightly the same as the term sawan for Javanese, yet the definition, causes, and healing rituals are highly different.

\section{Result and Discussion}

\section{Symbolic Communication Process of Kesandingan Ritual}

According to the ritual performers and the senior figures of Mentor village, kesandingan is the condition when the spirit of the ancestors (invisible creatures) 'sambang' (comes) to their descendants. They may be the ancestors of the father, mother, great-grandmother or others. They want to know their children and grandchildren. Sometimes, they miss their offspring or want to carry the child. The causes varies, so the preparation of the rituals is also different. Children cannot be exposed to a match after turning "aqilbaligh" or after circumcision. Kesandingan is understood as the event of a child who is 'emblazoned' by invisible creatures or the spirit of a deceased ancestor, such as a grandfather, grandmother, great-grandmother or others, either from the lineage of the mother or father.

On its history, kesandingan is a treatment that Mentor villagers for generations have trusted. Especially in the past, the dynamics of society were deeply thick with animism and dynamism. Accordingly, they believe that everything that happens to humans is related to the supernatural realm rather than medical treatment even though the medical had not developed as today.

Another aspect to note is on the signs that indicate if a toddler or child is experiencing comparability. The signs of pairing are quite easy to recognize. 
The child is suddenly fussing unusually, crying all the time, glaring in fear without cause and lasting for days.

The social construction of Mentor village community is related to the ritual of accompaniment. Ritual accompaniment is one of the cultural phenomena of traditional healing (ethnomedicine) passed on from generation to generation. Comparability is interesting because it is a cultural feature of ancestral heritage that is difficult to understand by logic, especially for nonindigenous people. After all, it is related to belief in supernatural powers.

As a cultural reality, comparability does not stand alone or believe in a particular group. However, kesandingan is a social construction of society that occurs over a long period. Thus, the social construction of the Mentor village community regarding this alignment is very strong. The community believes that the child will recover by performing a matching ritual. Even though people live with medical sophistication and affordable health facilities, they prefer 'alternative' treatments that are affordable and practical. In addition, a hereditary belief passed down from their ancestors also "legitimizes" the validity of the matching ritual to deal with fussy children, who did not stop crying and couldn't sleep, especially at night.

The accompaniment ritual aims to communicate with God, ancestral spirits or other invisible creatures. It is carried out when a child is believed to be 'on the cross' with the spirit of his deceased ancestor to ask for help, so the ancestral spirit immediately leaves and does not disturb the child anymore. Thus, the child will recover as usual. In this context, according to Sutan Alisyahbana, human thoughts, attitudes, and actions focuses on how to get the help of spirits or invisible creatures that disturb or hinder. There are various kinds of rites, incantations, prohibitions, and orders that fulfill life among society (Simuh, 1996).

Kesandingan ritual is one of the myths that the Mentor village community has believed for generations. Myths have a close relationship with the unseen because according to Frazer, in the past humans only used magic in solving life's problems that were beyond the limits of their ability and intellectual knowledge. The more advanced culture, the limit of human reason is still very narrow. Life problems that cannot be solved by reason are solved by using myths. Myth is also a narrative description or narrative about something sacred, which concerns extraordinary events outside of daily human experience. This narrative is generally manifested in stories about the supernatural world (Zainuddin, 2019) and Javanese supernatural world (Harwanto, 2020).

el Harakah Jurnal Budaya Islam Vol. 23 No. 1 Tahun 2021 
One of the characteristics of Kejawen's life is the love in myths. All Javanese behavior is often difficult to get rid of aspects of belief in certain things. That is why the mystical system of thinking will always dominate the behavior of Javanese. Javanese are known for the expression "wong Jowo iku nggoning semu" (Javanese people are sensitive to symbolic language). Symbolic language is very basic for Javanese (Mulyana, 2017; Niken \& Herawati, 2019) due to their ethical sensitivity (Damami, 2002).

Kesandingan ritual symbolizes the Mentor village community to 'communicate' with the transcendent because humans are unable to approach directly. The holy is transcendent while humans are corporal beings who are tied to their world. As Mircea Eliade stated, a symbol is a tool or means of recognizing the holy and the transcendent (Susanto, 1987).

Kesandingan ritual as a symbol of the Mentor village community to 'communicate' with the supernatural world is a conceptualization of one thing, a symbol exists for something. Symbols or collections of symbols work by connecting a concept, pattern, or form that produces meaning as a complex relationship between symbols, objects, and humans that involves denotation (shared meaning) and connotation (personal meaning). In this case, the power of symbols can lead anyone to believe, acknowledge, preserve or change perceptions of people's behavior in contact with reality. The power of symbols lies in not only their ability to represent reality but also reality represented through the use of symbolic logic (Fashri, 2007).

\section{The Symbolic Communication Process of Kesandingan Ritual}

The symbolic communication with the ritual accompaniment in Mentor Village, Sumberasih, Probolinggo comprises seven stages: 1) burning incense, 2 ) wiping incense smoke on the child's face, 3 ) giving the child a holy water to drink, 4) wiping the child's face with floral water, 5) preparing food, 6) praying on the child's bed, and 7) distributing food.

According to Auguste Conte, human thinking starts from belief in something unseen, which has supernatural (theological) powers, all dangers, diseases, disasters, death and so on-coming from supernatural powers (God). So, to refuse and keep away from these dangers, it is necessary to get closer to God, by making offerings by saying all the pujas and praises he offers (metaphysically) (Zainuddin, 2019).

These stages are symbolic interactions to translate and define new dimensions of reality regarding the cosmological and metaphysical relationships. 
According to Morris, both Levi-Strauss and Cassirer argue that symbols are "something artificial", "clues", and it belongs to the world of meaning. Human knowledge is symbolic (Zainuddin, 2019).

The objects and the series of obligatory stages in the companion ritual represented by the symbol are what the social group means. Humans communicate through symbols. On the one hand, symbols are formed through the dynamic of social interactions, constituted as empirical realities, inherited historically, and they have value-laden. They are references for insight, giving instructions for members of certain cultures to live their lives, media, communication messages, and social representations.

In this case, cultural knowledge is more than a collection of symbols, folk terms, and others (Geertz, 1992). Like other areas in Java, the Mentor Village Community in carrying out accompaniment rituals cannot be separated from the use of symbols that are full of meaning. In this context, Javanese society essentially has a distinctive culture as a symbolic society. As in everyday life, symbols are useful for mediation to convey a certain message, compile an epistemology and beliefs embraced. The symbol for Javanese society has become a very open simulation as a means or things essential, so the essential truth becomes blurred (Herusatoto, 2001).

Kesandingan ritual is a series of activities of the Mentor village community as a medium for communication with God, the ancestral spirit, carried out repeatedly by praying, bringing offerings and giving food to let the 'spirit or invisible creatures' leave immediately. Given that Islam is the only religion practiced by the Mentor village community, the religious dimension cannot be separated from kesandingan rituals, such as reading bismillah, and praying in a pure state.

In regard, Javanese Islam requires that the rites of circumcision, marriage and death be carried out according to Islamic law. Javanese Islam also believes that other aspects of Sharia-centric piety are free to choose (Zainuddin, 2019). The application of the microcosm/macrocosm to cosmologic, religious, social, and political thought transforms the character of mystical Sufi (Herusatoto, 2001), and in the context of mystical Sufi within Javanese Islam (Rubaidi, 2019; Huda, 2020; Rohma, 2020).

\section{The Symbolic Meaning of Kesandingan Ritual}

The components of meaning and symbol elements are language, physical reality, and feelings (Cassirer, 1987). To understand the meaning of the 
comparative ritual symbols among the community of Mentor Village, this study employs the theory of Helbert Blumer. It covers the urgency of meaning to one's actions, which includes one's attitude towards others based on meanings understood by them. Meaning is created by interaction with fellow humans who are modified through an interpretive process. In addition, humans do not only move because of the influence of stimuli either intrinsically or extrinsically, but they are creatures that are aware of themselves. Also, human relations in the community are influenced by socio-cultural processes and social structures, manifested through social interaction. Lastly, Blumer defines this level as non-symbolic and symbolic interactions (Fisher, 1986).

Kesandingan ritual symbol for the community of Mentor Village means: first, the dimension of Godhead. In practice, the divine dimension can be seen from several symbols that believe in God who is always alive, in the soul and divine will that governs the universe and has a moral relationship with mankind. In this discussion, the divine dimension is Islam. Kesandingan ritual is an acculturation of Hindhu-Budha and animism with Islamic values, such as reading bismillah, prayer, and making a wish during the ritual. It means asking Allah for help so that the 'spirit or invisible creatures' of the ancestor who disturb the child leave and he/she recovers immediately.

The second meaning is social dimension. The meaning of the social dimension in the matching ritual within the community gives goodness for self and for others:

1. Concern for others

In the accompaniment ritual, the prepared food is given to neighbors or relatives who have small children. Giving the food is a form of caring and sharing with others.

2. A close relationship among family members

A parallel child is the existence of 'spirit or invisible creatures' from the ancestor of the mother or father's lineage who is 'embracing' their children and grandchildren. Therefore, it contains valuable lessons to always care for family members to maintain a good relation.

3. A pray for relatives who have passed away

One of the important processes in the companion ritual is to pray for the "spirit or invisible creatures" of the ancestors to "return" to their natural world and not disturb the child, so the child recovers. It deals with the teaching to always pray for the relatives who have passed away. It shows cares for the descendants. The Prophet says, “... If a human dies, his deeds 
will stop, except for three cases, sadaqah jariyah (charity), useful knowledge, and pious children who always pray for their parents" (HR. Muslim). For the people of Mentor Village, matching ritual is intended to provide goodness in the following personal dimensions:

4. Sincerity

To implement this ritual of accompaniment, a family whose child experiences a pairing must prepare food according to the "instructions" of the traditional healer and gives it to neighbors or relatives who have small children. Therefore, one must learn to be sincere to share with others.

5. Recognition of the Supreme Being

The matching ritual plays as a form of a request to God Almighty to protect and ask for safety. So, it reminds us that humans are His creatures who have no power except by His will and, at the same time, recognition of the Supreme Being.

\section{Conclusion}

The symbolic communication process of kesandingan ritual in Mentor Village, Sumberasih, Probolinggo comprises seven stages: 1) burning incense, 2 ) wiping incense smoke on the child's face, 3 ) giving the child holy water to drink, 4) wiping the child's face with floral water, 5) preparing food, 6) praying on the child's bed, and 7) distributing food. Meanwhile, the symbolic meaning of kesandingan rhythm includes divine, social, and personal dimensions. This research provides insight to understand the existing rituals among people in Probolingo, so there is no misunderstanding in responding to the ritual, especially Javanese. Therefore, further studies can explore more and analyze it comprehensively.

\section{References}

Briggs, C. L., \& Nichter, M. (2018). Ethnomedicine. The International Encyclopedia of Anthropology, 1-3.

Cassirer, E. (1987). Manusia dan kebudayaan: Sebuah Essai tentang Manusia. Transl. Alois A. Nugroho. Jakarta: Gramedia.

Damami, M. (2002). Makna Agama dalam Masyarakat Jawa. Yogyakarta: LESFI.

Endaswara, S. (2002). Mistik Kejawen (Sinkretisme, Simbolisme, dan Sufisme dalam Budaya Spiritual Jawa). Penelitian Humaniora, 73-74.

el Harakah Jurnal Budaya Islam Vol. 23 No. 1 Tahun 2021 
Fashri, F. (2007). Penyingkapan Kuasa Simbol, Apropriasi Reflektif Pemikiran Pierre Bourdieu. Yogyakarta: Jux Tapos.

Fisher, B. A. (1986). Teori-teori Komunikasi: Perspektif Mekanistis, Psikologis, Interaksional, dan Pragmatis. Bandung: Remadja Karya.

Geertz, C. (1992). Tafsir Kebudayaan. Yogyakarta: Kanisius.

Harwanto, B. (2020). Contextualized Tirakat Form to Christian Spiritual Formation among Javanese. Klabat Theological Review, 1(1), 49-62.

Herusatoto, B. (2001). Simbolisme dalam Budaya Jawa. Yogyakarta: Hanindita Graha Widia.

Hilmi, D. \& Sa'diyah, H. (2020). The Meaning of Rebbe Ritual as an Interpretation of Shadaqah Jariyah in Probolinggo. el-Harakah, 22(1), $19-37$.

Huda, S. (2020). Sufi Healing Commodification throughout East Java Urban Environments. El Harakah, 22(2), 287-307.

Iskandar, P. (1981). Perilaku Pencegahan dan Penyembuhan Penyakit pada Bayi dan Anak. Laporan HEDERA 4. Yogyakarta: PPSPK, Universitas Gajah Mada.

Jacobs, J. (2011). The Cross-Generational Transmission of Trauma: Ritual and Emotion among Survivors of the Holocaust. Journal of Contemporary Ethnography 40(3), 342,361. https://doi.org/10.1177/0891241610387279.

Joyomartono, M. (2007). Paparan Kuliah Penghantar Antropologi Kesehatan. Semarang: Unnes Press.

Kardila, S. A. (2016). Ritual Pengobatan Turun Jin di Desa Rimba Melintang Kecamatan Rimba Melintang kabupaten Rokan Hilir. KOBA 3(1), 11-22.

Koentjaningrat (1985). Ritus Peralihan di Indonesia. Jakarta: Balai Pustaka.

Koentjaraningrat (1994). Kebudayaan Jawa. Jakarta: Balai Pustaka.

Manan, A. (2020). Islamic Educational Values in Life-Cycle Rituals: An Ethnographic Study in Kluet Timur Community, Aceh, Indonesia. In Global Perspectives on Teaching and Learning Paths in Islamic Education (pp. 118-134). IGI Global. 
Moleong, L. J. (2002). Metodologi Penelitian Kualitatif. Bandung: Remaja Rosda Karya.

Mulyana, A. (2017). Sekaten tradition: The ritual ceremony in Yogyakarta as acculturation reality of Javanese culture in Indonesia. International Journal of Humanities and Social Science Studies, 4 (2), 50-61.

Munip, A. (2018). The Rool of Al-Jailani's Hagiography Among Javanese Muslim in Yogyakarta. el-Harakah 20(2), 135.

Niken, E., \& Herawati, E. N. (2019, June). Nyadran Ceremony as an Introduction to Art in Kulonprogo Regency. In International Conference on Art and Arts Education (ICAAE 2018) (pp. 242-244). Atlantis Press.

Paloma, M. M. (2004). Sosiolagi Kontemporer. Jakarta: Raja Grafindo Persada.

Prawirorahardjono, P. (1986). Ngesti Kasampurnan. Jakarta: Depdikbud.

Ridwan, M., \& Sulaeman, S. (2020). Revisiting Traditional Communication in Indonesia: Why do Self-Immunity Rituals of Pelauw Indigenous Community, Moluccas. Technium Social Sciences Journal, 14, 173-192.

Rohma, Z. F. (2020). Sufistic Spirituality: Joint motive study in the tarekat Zawiyah Naqsabandiyah Haqqani Yogyakarta. El Harakah, 22(1), 59.

Rubaidi, R. (2019). Java Islam: Relationship of Javanese culture and Islamic mystism in the post-colonial study perspective. El Harakah, 21(1), 19.

Sakai, M. (2017). Still remembering the origins: The continuity of syncretic Islamic practice among the Gumay (Gumai) in South Sumatra, Indonesia. Indonesia and the Malay World, 45(131), 44-65.

Sande, A. (2000). The Norwegian "russefeiring". The use of alcohol as a ritual in the "rite of passage" to adulthood. Nordic Studies on Alcohol and Drugs, 17(5-6), 340-354. https://doi.org/10.1177/14550772500017005-603

Sari, D. P., Susanto, D., \& Marimin, M. (2020). The Form of Kejawen Islam in Nyanggar Janur Kuning Rituals in Indonesia. International Journal of Multicultural and Multireligious Understanding, 7(1), 623-628.

Sidorchuk, A. L. (2018). Childhood Trauma and the Feminine Principle: Healing Through Myth, Ritual, Dreamwork, and Embodiment (Doctoral dissertation, Pacifica Graduate Institute).

el Harakah Jurnal Budaya Islam Vol. 23 No. 1 Tahun 2021 
Sihabudin, A. (2011). Komunikasi Antar Budaya Satu Perspektif Multidimensi. Jakarta: Bumi Aksara.

Simuh (1996). Sufisme Jawa. Yogyakarta: Bentang Budaya.

Sobur, A. (2003). Semiotika Komunikasi. Bandung: Remaja Rosdakarya.

Sugiono (2008). Memahami Penelitian Kualitatif. Bandung: Alfabeta.

Susanto, P. H. (1987). Mitos Menurut Pengertian Mircea Eliade. Yogyakarta: Kanisius.

Watkins, N. (2020). And God Said,"Let There Be Ritual....”. International Bulletin of Mission Research, 44(2), 153-163. https://doi.org/10.1177/2396939319832

Zainuddin, I. (2019). Merawat Keberagaman Dalam Keragaman. Yogyakarta: Magnun Pustaka Utama. 